\title{
The Problem of Quality Management in Higher Education: Contrasting Views of the Teacher and the University
}

\author{
Leonid S. Zvyagin \\ Financial University under the Government of the Russian Federation (Financial University) \\ Moscow, Russian Federation \\ lszvyagin@fa.ru
}

\begin{abstract}
The problems of quality management of higher education in Russia are considered. There are two system levels of quality - at the macro level (branch of higher education) and micro level (University). Based on the analysis of higher education, the objective components of the quality of higher education at the macro level, including the structure of training of employees with higher education in areas of knowledge and levels of education, are revealed. It is shown that for mass higher education required by modern society, the quality of the University means the quality of its educational environment. The basic requirements for the educational environment of the University, which set the main directions of its improvement, as well as possible ways to improve the criteria and approaches of education authorities to control and manage the quality of mass University are formulated.
\end{abstract}

Keywords - higher education; quality; management; field of knowledge; level of education; mass and accessible education; profile of higher education; educational environment; individualization of education; innovations; criteria

\section{INTRODUCTION}

The transition of the Russian economy to market relations has revealed some problems that can be attributed both to the General state of the Russian education system and to the vocational school.

Rapidly changing market conditions; its uneven saturation: the shortage of some specialists, with an excess of others; unstable demand for specialists from employers; the elimination of state regulation of the labor market and the distribution of graduates; increased competition due to the increase in the number of non-state educational institutions and the expansion of paid education; low efficiency of educational processes due to the use of outdated teaching methods, all this predetermines the revision of approaches to quality management of modern education.

Meeting this ambitious challenge requires long-term interventions that may not always be limited to education systems. In particular, it is necessary to provide for the possibility of adapting educational programs and qualifications obtained as a result of their implementation to the requirements of the world labor markets; to expand training in the main world languages; to improve educational management, information activities and marketing; to promote the mobility of students and teaching staff and their employment.

But of particular importance for increasing the competitiveness of Russian professional education is, of course, improve its quality, so in the coming years it is expected first of all to fully combine education and scientific research, to upgrade the educational program of vocational education in General, taking into account the current state of science, scientific ideas about the world and practices.

At the institutional level, a key role should be given to the development and use of mutually acceptable criteria and mechanisms for the assessment and validation of the quality of vocational education, some elements of which are present in the well-functioning national quality assessment systems of a number of countries, such as France, Sweden, Denmark, the United Kingdom and others.

In recent years, there has been an ongoing debate among specialists as to which strategy should develop Russian education in the XXI century, which criteria for the quality of education are the most optimal and can provide the expected high results, and which methods and tools should be used in the process of managing the quality of education.

\section{ANALYSIS OF APPROACHES TO THE DEFINITION OF "QUALITY OF EDUCATION"}

The problem of the quality of education is one of the Central problems in modern educational policy and science, because it is connected with the solution of a set of tasks aimed at personal development, its preparation for life in a rapidly changing and contradictory world, a person with high moral aspirations and motives for highly professional work.

In the pedagogical theory and activity it is more and more realized that ignoring or belittling of a role in educational programs, practice of educational process of any element or type of the content of education causes huge damage to interests not only of the individual, but also all society which progress is directly connected with quality of education.

The phrase "quality of education" in the early 90-ies of XX century, first appeared in Russia in the Russian Federation Law "On education" (1992 and 1996), in an article on state control over the quality of education, which gave rise to a large 
number of different practices such control, initiated the development of relevant theoretical concepts, becoming a basic factor of stable growth of interest of scientists to this problem. Currently, the total number of publications on the quality of education is in the thousands.

In a generalized form, the quality of education is defined as a set of its properties and their manifestations that contribute to meeting human needs and meet the interests of society and the state.

At the same time, according to some researchers, graduates should be considered, on the one hand, as consumers (of information that they receive in an educational institution), on the other - as suppliers of their own knowledge and skills to the employer.

In addition, the results of education can be evaluated for different objects (children, teachers, school, University) on different parameters, in different dimensions and at different levels. And each time we are talking about different results. This determines the narrower (or special) content of the quality of education.

The quality of education of a specialist is carried out in the process of mastering the historically established content of material and spiritual culture. The formation of subjectivity is provided by the historically established system of education, and at the subsequent stages of personal development-by real life and specific professional activities. The quality of education is a personal feature necessary for a person to carry out a particular activity, including professional.

The quality of vocational education as a whole consists, on the one hand, of individual qualities, and on the other - is a system designed to solve specific professional problems. Therefore, the main link between the individual parameters is a standard professional task.

The main parameters of the quality of vocational education can be summarized as follows:

- mastered by a specialist fundamental models of solving professional problems;

- acquired skills and experience necessary to solve professional problems and elementary professional problems;

- $\quad$ skills of using research methods in the development of projects to solve problems in the professional sphere.

Thus, it is possible to identify the following characteristics that reveal the content of the concept of "quality of professional education" in scientific and applied aspects: cultural and historical conditionality, complexity, consistency, interdisciplinarity, focus, standardization, subjectivity.

\section{STATE OF THE PROBLEM OF EDUCATION QUALITY MANAGEMENT}

The state of the problem of quality management of modern education is determined primarily by environmental factors, namely the socio-economic conditions of the subjects, the most important component of which is the labor market.
The world of work is changing radically, and much of the knowledge that students acquire during their initial training is rapidly becoming obsolete. Continuous and interactive partnerships with the productive sector are essential and should be integrated into the overall objectives and activities of educational institutions. Vocational education has not escaped the scope and urgency with which the need for educational reform to meet economic needs has manifested itself at the political level.

The world Bank A. Adams, D. Middleton and Seiderman in his article in the UNESCO journal "Prospects. Education issues" rightly point out: "closer coordination of economic and educational policies, as well as diversification of funds allocated for vocational and technical education should be complemented by measures to improve the flexibility of state training structures, their effectiveness. If employment opportunities are available after training and if education is linked to employment, the impact of vocational school may be higher than that of the General education system."

The program of development of professional education of Russia, which is the main conceptual document in the field of professional education, interprets the tasks in the same direction. As the main objectives of development, it definesproviding a given quality of education, improving the competitiveness and professional mobility of graduates in the labor market. In terms of market being in a constant state of change, planning, professional education and training cannot maintain its mechanical nature. From a simple calculation, vocational education planning becomes a complex equation that must take into account many factors that differ in their predictability.

Planning is an integral element of the quality management process of national education, which is generally defined in the national literature. Thus, considering learning as a management process, the following functional components of pedagogical activity are distinguished:

1. Targeting - acts as a process of designing the personality of the student, educated, or the formation of a model of the future specialist.

2. Information - includes the content of training and education.

3. Forecasting - is the prediction of near and far psychological learning outcomes in certain conditions of its implementation.

4. Decision-making is aimed at choosing the best ways of individual and collective influence on the personality.

5. Organization of execution-associated with the implementation of educational plans, programs and pedagogical decisions.

6. Communication - represents various forms and ways of interaction of participants of educational process.

7. Control - involves assessing the actual results of training and education in different time intervals. 
8. Correction - means elimination of undesirable deviations and changes in mentality and behavior of participants of educational process.

All the constituent elements of management form a single functional system of training, in which the system-forming factor is the purpose of training and education, which are oriented and which are subject to all other management functions. In turn, under the management of graduate quality, some researchers understand a constant, systematic, purposeful process of influence at all levels on the factors and conditions that ensure the formation of the future specialist of optimal quality and the full use of his knowledge and skills.

In theory, everything looks quite clear, but in practice the formation of the future specialists of Russia in the classic educational institutions and often using technologies and practices of education which have developed in the past centuries and promoting conflict educational reality, the study of stereotypes of students, teachers and administrators relative to each other and relative to their educational experience.

The internal contradictions of the reality of education are due to the fact that the subjects of the educational process administration, teachers and students, coexist in a single space and time, but most often do not have common goals, needs, motivations and social practices. The discontinuity of information, communication and disciplinary space and time reduces the effectiveness of the educational process, prevents the value dialogue of generations, inhibits the formation of a new corporate culture of the University. Parallel coexistence of two interpretations of the educational process - as the exchange of services and as communication "teacher-student" - distorts its perception by all subjects, retains the dominance of traditional learning technologies over innovative ones.

At the same time, two conceptually different strategies constantly face in the discussion field of the problems of modern education: modernization of Russian education on the Western model or development and multiplication of national features of the education system.

Supporters of Western standards of quality of education consider the student the main consumer of educational services, which reverses the classical concept of the purpose of vocational education as a secondary socialization of the individual, giving him social and role knowledge and value orientations.

The whole system of foreign approaches to the problem of quality management in the most concentrated form is presented in the concept of TQM - Total Quality Management (Total quality management), which has its expression in the international quality standards ISO 9000 series. These standards provide terms and definitions, procedures for the development and implementation of quality systems in organizations and institutions, methods of quality management of main and auxiliary processes, etc. The methodology of the theory and practice of quality management is based on management in the field of material production, without taking into account the specifics of education.

As a result, education as a social institution and the teacher as his personal embodiment lose the original meaning of their existence. The teacher acts as a personalized service, but not as a teacher and educator.

Some authors express categorically that the americanization of society, which we see in most countries, can lead to the destruction of science and culture of modern humanity in Russia. The threat of an age of ignorance seems very real. Bureaucracy and administration begin to triumph, destroying education, science and culture in General. Students as a specific social group, which has its own political will in the system of existing power relations, now degrades. This layer of civil society needs state support programs and, in principle, cannot exist without this support. The widespread commercialization of public education results in the reduction and destruction of this important social group.

Given the current situation, I would like to note that the officially stated goal of assessing the quality of education and its maintenance at the level of set standards does not detract from national traditions, rich experience and priorities of the Russian education system. The concept of quality of Russian education should be based on the analysis and synthesis of the best achievements of world and national science and practice. UNESCO, in particular, emphasizes that the development of education cannot be realized within rigid or imposed structures, that there is a failure of development strategies based on mere copying or imposing models, that more and more people and institutions are coming to realize that in all regions the direct adoption of foreign concepts and values and the disregard of regional and national cultures and philosophies have negative consequences for education.

The duality of modern social and scientific consciousness contributes a significant amount of uncertainty to the development of the concept of Russian education and its content, damages the quality of education at all levels: from school to higher education.

\section{THE PROBLEM OF ASSESSING THE QUALITY OF EDUCATION}

The task of assessing the quality of education is no less difficult today. Traditionally, the assessment of the quality of training of students and graduates is carried out by means of control, with the help of various control tasks, questions, practical tasks. Means of control are developed on specialties taking into account the principle of continuity of professional education and future professional activity. Teachers develop tasks on the basis of system-structural didactics, taking into account the following levels of assimilation: recognition; reproduction; reproduction of application; synthesis. However, in these tasks, as a rule, do not reflect the methods of determining the level of readiness and ability of students to apply their knowledge in practice.

It is no secret that the Russian state standards of higher and secondary vocational education are based on General theoretical rather than practical training aimed at the ability to act in a specific professional situation. In the national state standards there is no description of connection and sequence of realization of separate disciplines with the qualification characteristic of the graduate. The state does not set integral 
goals and objectives for traditional discipline. The purpose of the discipline is, in fact, not the formation of needs and skills in the future to use its scientific content, but only the factual assimilation of scientific information, most often - at the level of memorization. The student in this case is required to attend lectures and a clear answer to the examiner in the program.

The level of development of theoretical knowledge by a student is set by teachers, based on their subjective ideas about the control of learning outcomes, and not on the integral ideas about the qualification of a specialist. As a result, fundamental models and methods of training are broadcast, due attention is not paid to the use of theoretical knowledge as a methodological tool for a holistic study of certain professional situations. Pedagogical and scientific activity of teachers is poorly connected with the future professional activity of graduates.

The student has a superficial idea of the relationship of training and the main professional tasks that he will have to solve in his professional activity, the content and forms of selftraining, methods of organizing the educational process, the system and criteria for external evaluation of knowledge, which he first encounters only when applying for a job.

While in most European countries there is a development of national systems of external assessment of the quality of education, in Russian educational institutions efforts are aimed at creating an internal system of assessment of the quality of training.

\section{CONCLUSION}

The analysis of domestic literature shows that the basic procedures for assessing the quality of the educational process are characterized by such features as: a) a wide range of indicators to assess the qualitative characteristics; b) the use of evaluation scales; C) the use of expert procedures; d) the use of weights for individual indicators, tests, tasks, other methods of didactic control and methods of pedagogical analysis and diagnosis. Currently, it is necessary to change the paradigm of assessing the quality of education from General theoretical to practice-oriented, which meets the needs of the modern labor market, provides guarantees of demand, competitiveness of the future specialist. At the same time, the main changes must occur, first of all, at the value level of the main subjects of the educational process: teachers and students who need to develop new forms of cooperation and get rid of stereotypes.

\section{REFERENCES}

[1] Baieva N.A. Social state and its main criteria. Sb. nauch. trudov yurid. fak. SevKavGTU [SB. nauch. works of the faculty of law. FAK. Sevkavgtu]. Stavropol, 2004. Vol. 6, p. 26. (In Russian)

[2] Krivosheev V.A. Social'noe partnerstvo $v$ sfere professional'nogo obrazovaniya naseleniya [Social partnership in the sphere of professional education of the population]. Saratov, 2003. (In Russian)

[3] Kazimov K.G. Vzaimodejstvie uchrezhdenij professional'nogo obrazovaniya s rynkom truda [Interaction of vocational education institutions with the labor market]. M., 2005. 204 pp. (In Russian)

[4] Kazimov K.G. Rynok truda i zanyatost' naseleniya [Labor Market and employment]. M., 2005. 356 pp. (In Russian)

[5] Mikheev V.A., Mikheev L.V. Social'noe partnerstvo: teoriya, politika, praktika [Social partnership: theory, politic, practice]. M., 2003. (In Russian)

[6] Smirnov I.P. CHelovek - obrazovanie - professiya - lichnost' [Maneducation-profession-personality]. M., 2002. (In Russian)

[7] Tkachenko E.V., Safonova E.G. et al. Social'noe partnerstvo uchrezhdenij professional'nogo obrazovaniya [Social partnership of vocational education]. Ekaterinburg, 2003. (In Russian)

[8] Moshnyaga V.P. Mezhdunarodnyj opyt social'noj politiki i so- cial'noj raboty: kurs lekcij [International experience of social policy and social work: a course of lectures]. M., 2006. (In Russian)

[9] Rol' social'nogo partnerstva v formirovanii evropejskogo social'nogo prostranstva. Ed. M.V. Kargalovoj. [The Role of social partnership in the formation of the European social space Russ ed. M.V. Kargalova]. Dokl. in-ta Evropy RAN (DIE RAN) [Doc. Institute of Europe RAS (DIE RAS)]. M., 2003. No. 119. Pp. 117-118. (In Russian)

[10] Schmitter F. Neokorporativizm [Neocorporativism]. Polis Publ.. 1997. No. 2. Pp. 14-22. (In Russian)

[11] Shulus A.A. Rossijskaya model' social'nogo partnerstva: perspektivy razvitiya. [Russian model of social partnership: prospects of development]. CHelovek i trud [Man and labor]. 2007. No. 4. Pp. 52-62. (In Russian) 